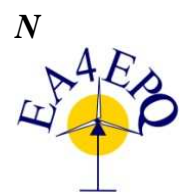

International Conference on Renewable Energies and Power Quality (ICREPQ'15)

La Coruña (Spain), $25^{\text {th }}$ to $27^{\text {th }}$ March, 2015

Renewable Energy and Pourer Qualiny. Fournal (RE\&PQJ)

ISSN 2172-038 X, No.13, April 2015

\title{
Electricity generation from tidal power in artificial "albúfera" in the Rio Negro Province, Argentina
}

\author{
Phd. Luis Bertani ${ }^{1}$ - MSc. Carlos Labriola ${ }^{2}$ - Eng. Aiel Marchegiani ${ }^{3}-$ Eng. Orlando Audisio ${ }^{3}$ \\ - Mr. Samuel Troncoso Schenker ${ }^{2}$ \\ ${ }^{1}$ Department of Geography - Faculty of Human Sciences \\ ${ }^{2}$ Department of Electrotecnia - Faculty of Engineering \\ ${ }^{2}$ Department of Mechanics - Faculty of Engineering \\ Universidad Nacional del Comahue - Buenos Aires 1400, Neuquén (CP:8300) - Argentina \\ bertani8300@gmail.com - carloslabriola54@yahoo.com.ar - ariel.marchegiani@ fain.uncoma.edu.ar \\ orlando.audisio@fain.uncoma.edu.ar - samueltroncoso24@gmail.com \\ $+542994488305$
}

\begin{abstract}
In this paper we consider the possibility of using the absolute depression "bajo del Gualicho" (- $72 \mathrm{~m})$, Río Negro Province, Argentina, to generate electricity by means of a connection with the sea in the Gulf of San Matias, located about $25 \mathrm{~km}$ to the East [1]. This would allow the formation of a large lake that would create an "artificial albúfera" which will cover an area of about $1234 \mathrm{~km}^{2}$.

This lake will be exposed to tidal by means of a combination of a channel and four tunels located between the sea and the lake. Taking the reference of Puerto San Antonio Este, the average tidal range reaches $6.73 \mathrm{~m}$ [2], so that each high tide (lasting 6 hours. 20 minutes) would the water flow to the lake and the sea at low tide it would travel in the opposite direction.

This project is made by means of a multidisciplinary research group with advice of Hydraulic Laboratory of University of La Plata and Renewable Energy Group of Academic Unit of Caleta Olivia [3], National University of Austral patagonia, Province of Santa Cruz. Also this project has the endorsement of Government of Rio Negro Province.
\end{abstract}

\section{Key words}

Tidal, Renewable Energy, Hydrokinetic turbine, albufera.

\section{Introduction - The Tides}

The phenomenon of tides, despite being well-known and relevant to humanity since people learned to sail, his explanation, calculation and forecasting issues are developed in the last centuries.

Isaac Newton took the first step by analyzing the impact of the attraction of the moon and the sun on the waters, in the early eighteenth century. At the end of this century Laplace discovered the resonance effects of the waves on the coast. George Darwin discovered in 1879 the ratio of the tides with the distance to the moon. In 1902 Henri Poincare established the basic equations which govern the tides and from there scientists were able to develop numerical methods and even scale models.

The Earth is almost a perfect sphere, where Moon and Sun, continually changing their position on it, producing movements of ocean currents in seas and oceans. It is also possible to add the effects of the rotation of the Earth on its axis and variations in seafloor depth affecting the direction and intensity of these flows [4].

Fig. 1 and 2 shows the action of Moon and Sun depending on the position of them with resoect the Earth,

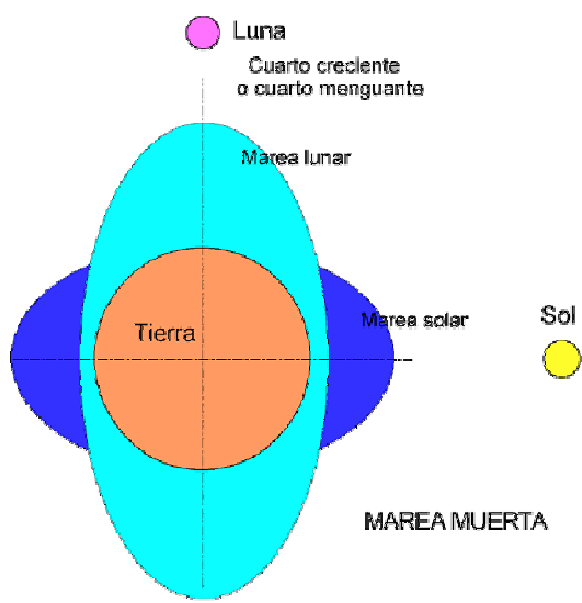

Fig. 1 Mon and Sun at $90^{\circ}$

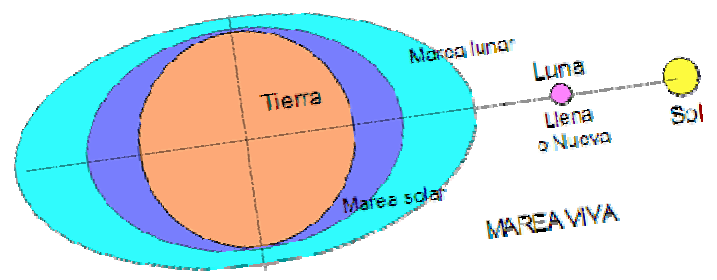

Fig. 2 Moon and Sun at $0^{\circ}$

The most important effect appears in areas where the Moon is near the horizon because the gap between attraction and centripetal force acts producing currents affecting the entire 
volume of water in depth, with the diference on wind effects which is only on surface mass.

Because of the Moon is never far away from Ecuador, where gravitational forces of Moon and Earth on the water are balanced, this situation combined with terrestrial rotation, produce areas where the water moves more at very high latitudes. The movement consists of the entire mass of water along meridians, addressing low latitudes. Besides the Coriolis acceleration has effects on the surface of the Earth, where the water velocity produced has more value at low latitudes than at high flows diverted to the West [4].

Assuming that the sea depth is raised by the proximity of the continent, the height of the tidal wave increases with the square of the ratio of depths neglecting friction with the seabed. Consequently shorelines, especially those that are at East, increase tidal level twice daily, as in the case of Patagonia.

Keep in mind that the moon's orbit is sometimes above or below the ecliptic, therefore sea movements continuously change in complex form in a sequence that repeats every 19 years, and also the distance betwenn Earth and Moon varies by $10 \%$ every 28 days.

The Sun alone would produce lower amplitude as half Moon tides. Actually the effects of the Moon and Sun are superimposed and this complicates mare the actions since the relative position between them changes every 29 days (Se Fig. 1 and 2). Once or twice a year the Moon, Sun and Earth are at Eclipse position and an abnormally high tide occurs. Where the Sun, Moon and Earth are perfectly aligned with the Moon at perigee and exceptional tide or Saxby occurs, (one in a century) as happened in the English Channel in 1967 where the $11 \mathrm{~km}$ sea receded at low tide and then climbed 22 meters level.

\section{Bajo del Gualicho Project}

The goal of this project is to estimate:

- The instalated power and energy with the present technology.

- The return of capital by means of green bones.

- To estimate the cost of the global work to do.

The word "albúfera" is identified with nearshore places that are flooded by the sea as a result of the tides with varied depths places. In Argentina, the lagoon of Mar Chiquita in Buenos Aires Province is a classic example of a natural pond.

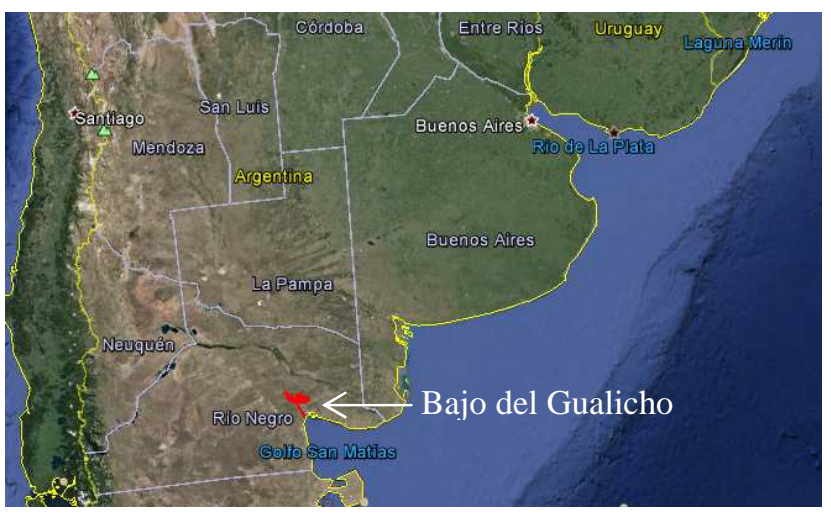

Fig. 1: Location of Bajo del Gualicho

The Bajo del Gualicho is $25 / 30 \mathrm{~km}$ from the seaside (Fig.1 and 2 ). At the level 0 , the future borders of albúfera lakr has more than $20 \mathrm{~km}$ long and $80 \mathrm{~km}$ wide [5]. This lake is connected with the sea, in the Gulf of San Matias, through channels first (about $10 \mathrm{~km})$ and then tunnels $(15 \mathrm{~km})$. This combination of channels and tunels is because of a plato around the albufera with almost $15 \mathrm{~km}$ long.
The Technology to use is the following:

1 -Channels of $100 \mathrm{~m}$ wude, $25 \mathrm{~m}$ depth and $10 \mathrm{~km}$ long with concrete cover to avoid erosion.

2 -Tunels of $15 \mathrm{~m}$ of diamenetr and $15 \mathrm{~km}$ long.

3 - Hydrokinetic turbines of $200 \mathrm{~kW}$, two per column.

4- Bulbo turbines of $8 \mathrm{MW}$ in tunels.

Fig. 2 shows the lake at 0 level to the sea, this is about $1234 \mathrm{~km} 2$, 1.5 times the area of Ramos Mexia lake of El Chocón Hydropower station ("The Construcction of the Century" during 1970s). Fig. 2 shows the distribution of some tunels and channels from the albúfera to the sea near San Antonio city, in Rio Negro Province.

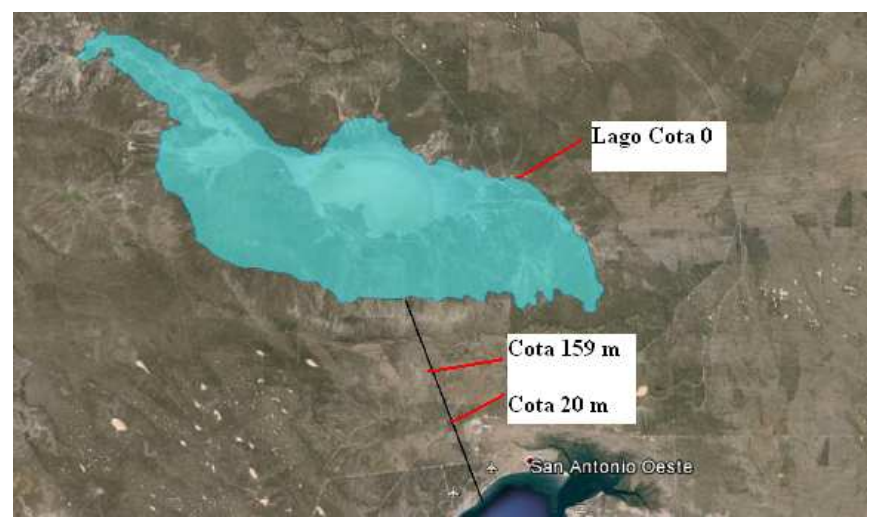

Fig. 2: Albufera lake in Bajo del Gualicho

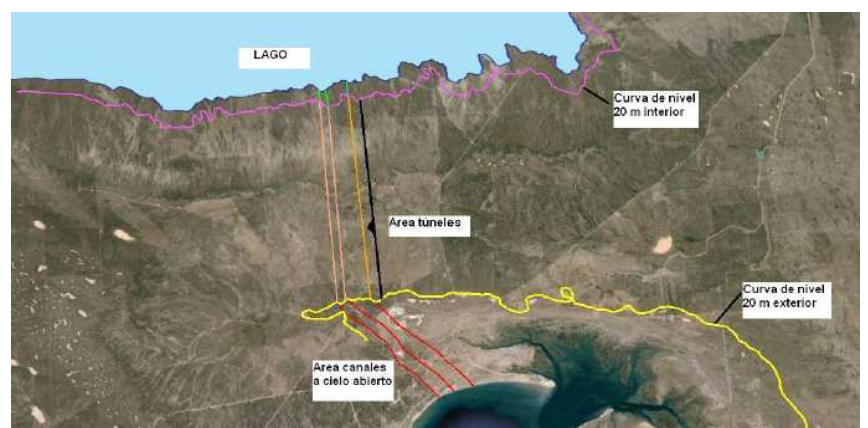

Fig. 3: Tunels and Channels from Albufera to the sea.

\section{Technology proposed}

The tunneling machines that fit the project should have a diameter between 15 and $20 \mathrm{~m}$. The last tunelling works in the world have enabled these technologies are developed and also Argentina has one for rail tunnels.

The excavated soil is relatively soft (clay) [6] which would allow excavation without mishap. In the case of conventional channels conventional machines would be used on large surface excavations.

In the case of hydrokinetic turbines, similar to those developed and commercial supply in the UK of $200 \mathrm{~kW}$ (two column) are suitable for this project. Larger turbines would increase the cost and decrease the installed capacity.

These turbines can be combined with bulb ones in the entrance or end of channels, increasing the installed power.

There is no an unique combination of turbines in type and location, we can make several combinations in different places of channels and tunnels. Here we have presented only one of them to get an overall estimation.

Fig. 4 shows tunneling machines and Fig. 5 shows HKT tipes where de double ones at right hand are proposed for this project. 


\begin{tabular}{|c|c|c|c|}
\hline Caracte-risticas & $\begin{array}{l}\text { Método Alemán. } \\
\text { Método Belga. } \\
\text { Fullface. }\end{array}$ & TBM & EPB \\
\hline $\begin{array}{l}\text { Proceso de } \\
\text { construcción }\end{array}$ & $\begin{array}{l}\text { Se utiliza explosivos, } \\
\text { luego una maquina } \\
\text { remueve el material para } \\
\text { luego cementar la } \\
\text { superficie escavada. } \\
\end{array}$ & $\begin{array}{l}\text { Una sola maquina } \\
\text { realiza todo el trabajo. } \\
\text { En particular se colocan } \\
\text { bloques de cemento. }\end{array}$ & $\begin{array}{l}\text { Una sola maquina realiza } \\
\text { todo el trabajo. } \\
\text { La maquina tiene una } \\
\text { Escudo metálico para las } \\
\text { presiones de tierra. }\end{array}$ \\
\hline \multicolumn{4}{|l|}{ Imagen } \\
\hline $\begin{array}{l}\text { Diámetro } \\
\text { máximo }[\mathrm{m}]\end{array}$ & 11 & 15,2 & 15,2 \\
\hline $\begin{array}{l}\text { Implementados } \\
\text { en Argentina }\end{array}$ & $\mathrm{Si}$ & No & No \\
\hline Particularidades & $\begin{array}{l}\text { Tres métodos que difieren } \\
\text { en el proceso. }\end{array}$ & $\begin{array}{l}\text { Costo } 40 \text { millones de } \\
\text { euros. } \\
\text { Potencia } 12 \mathrm{Mw} \text {. } \\
\text { Peso } 4366 \mathrm{t} \text {. } \\
\end{array}$ & $\begin{array}{l}\text { Avance de } 36 \mathrm{~m} \text { /dia. } \\
\text { Potencia } 22 \mathrm{Mw} \text {. } \\
\text { Peso } 4364 \mathrm{t} \text {. }\end{array}$ \\
\hline Ventajas & $\begin{array}{l}\text { Más económico. } \\
\text { Se ha implementado en el } \\
\text { pais. }\end{array}$ & $\begin{array}{l}\text { Diámetro mayor. } \\
\text { Forma circular. } \\
\text { Factor de riesgo bajo. }\end{array}$ & $\begin{array}{l}\text { Tiene un escudo. } \\
\text { Diámetro mayor. } \\
\text { Forma circular. } \\
\text { Factor de riesgo bajo. }\end{array}$ \\
\hline Desventaja & $\begin{array}{l}\text { Factor de riesgo alto. } \\
\text { El túnel no forma una } \\
\text { circunferencia. }\end{array}$ & $\begin{array}{l}\text { No posee escudo. } \\
\text { No se ha implementado } \\
\text { en el pais. } \\
\text { Costos elevados. }\end{array}$ & $\begin{array}{l}\text { No se ha implementado en } \\
\text { el pais. } \\
\text { Costoso elevados. }\end{array}$ \\
\hline
\end{tabular}

Fig. 4: Tunelling machines [7].

\begin{tabular}{|c|c|c|c|}
\hline Caracte-risticas & Alstrom & Nova Scotia & SeaGen \\
\hline Imagen & & & \\
\hline Diámetro máximo & 18 & 10 & 16 \\
\hline $\begin{array}{l}\text { Implementados en } \\
\text { Argentina }\end{array}$ & No & No & No \\
\hline $\begin{array}{l}\text { Admite flujos } \\
\text { bidireccionales. }\end{array}$ & No & $\mathrm{Si}$ & $\mathrm{Si}$ \\
\hline Particularidades & $\begin{array}{l}\text { Potencia } 1 \mathrm{Mw} \text {. } \\
\text { Longitud } 22 \mathrm{~m} \\
\text { Peso } 150 \mathrm{t} \text {. }\end{array}$ & $\begin{array}{l}\text { Potencia } 1 \mathrm{Mw} \text {. } \\
\text { Su forma no afecta a las } \\
\text { especies marinas. } \\
\text { Generador magnético. }\end{array}$ & $\begin{array}{l}\text { Potencia } 1,2 \mathrm{Mw} \text { (en } \\
\text { mareas con v }= \\
0,51 \mathrm{~m} / \mathrm{s} \text { ). } \\
\text { Con dos rotores, es similar } \\
\text { a la turbina eólica. }\end{array}$ \\
\hline Ventajas & $\begin{array}{l}\text { Simple. } \\
\text { Fácil de transportar } \\
\text { Instalada y retirada } \\
\text { fácilmente en un mismo } \\
\text { ciclo de marea utilizando } \\
\text { buques pequeños. } \\
\text { Con barquilla inteligente } \\
\text { que permite administrar la } \\
\text { carga. }\end{array}$ & $\begin{array}{l}\text { Admite flujos } \\
\text { bidireccionales. } \\
\text { No necesita lubricación. } \\
\text { Presenta una forma sin } \\
\text { puntas. }\end{array}$ & $\begin{array}{l}\text { Admite flujos } \\
\text { bidireccionales. } \\
\text { Similitud a la turbina } \\
\text { eólica. }\end{array}$ \\
\hline
\end{tabular}

Fig. 5 Hydrokinetic machines [7]

Fig. 6 shows the last generation of bulb turbines [7] produced in Brazil.

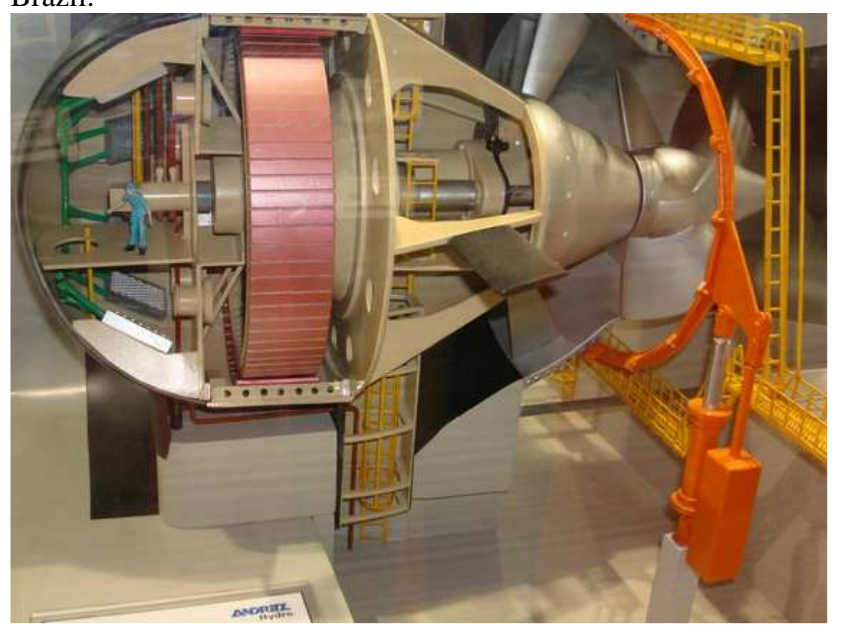

\section{Energy Estimation and Green Bonds}

In the case of the energy supplied, the following considerations con be made:

1. The artificial lake will have two daily tides, which 4 hours will considered for electrical generation. The beginning $(1 \mathrm{~h}$.) and the end (1h.) of the tidal, the level for water storage is negligible.

2. The power installated is estimated with the size and number of channels and tunels. Hidrokinetics turbines will placed in the channel with a combination of $2-1-2-1 \ldots$ in a distance of $100 \mathrm{~m}$ between each line of 3 or 2 turbines. A bulb turbine is located in each tunel (4 per channel).

3.This energy is regular, everyday you can get four times generation: two of $4 \mathrm{hs}$ of high tide and two of $4 \mathrm{hs}$ of low tide (Total 16hs. Of electrical generation in average).

4. It is predictable because you know at what time the tides occur (high and low tide) per day, so it is easy to integrate the unit commission of generators into the Argentinean Electric System (AES).

5. The fossil fuel with more emissions is taken as reference for avioded green house gases used for green bonds estimation. Steam turbines in AES use fuel oil as fuel, Table 1 shows the comparison of emissions.

6. As a control value of green bonds takes $\mathrm{U} \$ \mathrm{~S} 6.6 / \mathrm{tonCO}_{2}$ in December 2013 [7].

Table 1: Conversion and emission factor per fuel

\begin{tabular}{|c|c|c|c|}
\hline Fuel & $\begin{array}{c}\text { Conversión } \\
\text { Factor }[8]\end{array}$ & $\begin{array}{c}\text { Emisión } \\
\text { factor }[8]\end{array}$ & tonCO $/$ MWh \\
\hline Fuel oil & $\begin{array}{c}11,16 \\
\mathrm{KWh} / \mathrm{Kg}\end{array}$ & $\begin{array}{c}3,05 \\
\mathrm{KgCO} 2 / \mathrm{Kg}\end{array}$ & 0.273 \\
\hline Gas oil & $\begin{array}{c}11,78 \\
\mathrm{KWh} / \mathrm{Kg}\end{array}$ & $\begin{array}{c}3,1 \\
\mathrm{KgCO} 2 / \mathrm{Kg}\end{array}$ & 0.263 \\
\hline Nat. gas & $\begin{array}{c}10,65 \\
\mathrm{KWh} / \mathrm{m}^{3}\end{array}$ & $\begin{array}{c}2,15 \\
\mathrm{KgCO} 2 / \mathrm{m}^{3}\end{array}$ & 0.202 \\
\hline Carbon & $\begin{array}{c}7,09 \\
\mathrm{KWh} / \mathrm{Kg}\end{array}$ & $\begin{array}{c}2,53 \\
\mathrm{KgCO} 2 / \mathrm{Kg}\end{array}$ & 0.357 \\
\hline
\end{tabular}

The useful border of the lake has $15 \mathrm{~km}$ long, the channels width is $100 \mathrm{~m}$ and the embankment width between channls is $50 \mathrm{~m}$, so there will be 100 channles with $10 \mathrm{~km}$ long.

The hydrokinetic turbines (HKT) will be in arrangements of 2-1$2 \ldots$ separated $120 \mathrm{~m}$ each line of 2 or 1 . There will be 83 lines of turbines (two per column), 42 with 2 column and 41 with 1 ones.

The total of turbines per channel will be 125 columns with 2 machines/column will be 250 turbines per channel. The total Installed Power will be:

250 turbines $\times 200 \mathrm{~kW} \times 100$ channels $=5000 \mathrm{MW}$

In the case of Bulb turbines of 10MW per machine, there will be 4 tunnels per channel, resulting in 400 turbines. The total Installed Power of bulb turbines will be:

$10 \mathrm{MW} /$ bulb x 400turbines $=4000 \mathrm{MW}$

Table 2 shows the estimation of total installed power and energy/year:

Table 2: Installed Power and Energy /year

\begin{tabular}{|l|r|r|r|r|}
\hline Turbine & $\begin{array}{l}\text { Power } \\
\text { (MW) }\end{array}$ & $\begin{array}{l}\text { Hours } \\
\text { /day } \\
\text { (h) }\end{array}$ & $\begin{array}{l}\text { Energy/ } \\
\text { day } \\
\text { (MWh) }\end{array}$ & $\begin{array}{l}\text { Energy/ } \\
\text { Year } \\
\text { (TWh) }\end{array}$ \\
\hline Hydrokinetic & 5000 & 16 & 80000 & 29,20 \\
\hline Bulb & 4000 & 16 & 64000 & 23,36 \\
\hline Total & 9000 & 16 & 144000 & 52,56 \\
\hline
\end{tabular}

Taking into account Table 1, Fuel Oil is an imported fuel for Steam turbines and Mineral Carbon is used for only one power station with local production (Rio Turbio, Santa Cruz province). 
Fuel Oil should be replaced by Renewable Energy reducing external dependence of it. In this way, the calculation of green bonds is in table 3 :

Table 3: Return of Capital with Green Bonds.

\begin{tabular}{|c|c|c|c|c|}
\hline $\begin{array}{c}\text { Energy/ } \\
\text { Year }\end{array}$ & $\begin{array}{c}\text { Convresion } \\
\text { factor }\end{array}$ & $\begin{array}{c}\mathrm{CO}_{2} \\
\text { avoided }\end{array}$ & $\begin{array}{l}\text { Green } \\
\text { Bonds }\end{array}$ & $\begin{array}{c}\text { Total } \\
\text { G.Bonds }\end{array}$ \\
\hline 52,56 & 0,273 & 14348880 & 6,6 & 94,7 \\
\hline TWh & tonCO $\mathrm{O}_{2} / \mathrm{MWh}$ & tonCO ${ }_{2}$ & $\mathrm{U} \$ \mathrm{~S}$ & $10^{6} \mathrm{U} \$ \mathrm{~S}$ \\
\hline
\end{tabular}

\section{Global Cost Estimation}

Table 4 shows an estimation of costs, considering the last cost of installation of renewable energy devices in Argentina:

\begin{tabular}{|l|c|c|c|c|}
\hline $\begin{array}{c}\text { Installations } \\
\text { and } \\
\text { Construction }\end{array}$ & $\begin{array}{c}\text { Value/ } \\
\text { unit } \\
\mathbf{U} \$ \mathbf{S}\end{array}$ & $\begin{array}{c}\mathbf{N}^{\mathbf{0}} \\
\mathbf{M a c h} .\end{array}$ & $\begin{array}{c}\text { Power } \\
\mathbf{k W}\end{array}$ & $\begin{array}{c}\text { Cost } \\
\mathbf{1 0}^{\mathbf{6}} \text {. U\$S }\end{array}$ \\
\hline HKT & $\begin{array}{c}3000 / \mathrm{kW} \\
{[10]}\end{array}$ & 25000 & 200 & 15000 \\
\hline Bulb & $\begin{array}{c}3000 / \mathrm{kW} \\
{[10]}\end{array}$ & 400 & 10000 & 12000 \\
\hline $\begin{array}{l}\text { Channels } \\
\text { 100x15000x20m }\end{array}$ & $2 / \mathrm{m}^{3}$ & 100 & --- & 4500 \\
\hline $\begin{array}{l}\text { Tunel } \\
\text { \$:15mx15000m }\end{array}$ & $5 / \mathrm{m}^{3}$ & --- & --- & 5301 \\
\hline Concrete & & & & 9000 \\
\hline \multicolumn{2}{|r|r|}{} & TOTAL & 45801 \\
\hline
\end{tabular}

\section{Analysis of results}

The estimated installed power is similar to half of demand for Argentina in 2014 and the overall estimated cost including civil work is about U S5000/kW installed.

The average energy needed for Argentina per year is about $170 \mathrm{TWh}$. The energy produced annually by El Gualicho is almost $17 \%$ of the country.

The capital return by green bonds is about $\mathrm{U} \$ \mathrm{~S} 100.10^{6}$ which is not a very high value today. But in medium-term bonds will reach U\$S 40/ton of $\mathrm{CO}_{2}$ [8], which would give us a figure close U\$S600.10 $10^{6}(1,5 \%$ of the global investment). It is necesary to wait when prices of the green bonds reach that figure to certify the $\mathrm{CO} 2$ avoided.

\section{Conclusions and Recomendations}

\subsection{Comclusions:}

This project is a big one and will last more than 10 years, so this one should be included in a national enegry policy.

This type of project allows having installed capacity according to demand growth (800MW / year) or or a big part of it. Such power can be increased or decreased according to the variations of demand growth.

Argentina imported fossil fuel, particularly fuel oil worth U\$S8000. $10^{6} /$ year [11]. Such figure would permits to contruct up to 20 combinations of Channel/tunel with instaled machines per year.
During the second year hydrokinetic turbines installed, could generate energy with capital return, compared with a traditional tide-hydraulic installation which last al least 4 years [12].

\subsection{Recomendations:}

This work take into account only energy bussines, but also there is a touristic one, on the banks of the lake with width of at least $3 \mathrm{~km}$, which gives us an area of $600 \mathrm{~km} 2$, three times the area of the city of Buenos Aires. The capital raised from sales of such land should be estimated as part of the return on capital for the project.

\section{References}

[1] Data from "Instituto Geográfico Militar" of Argentina, Maps 642/13.

[2] Data from "Servicio de Hidrografía Naval" of Argentina. Tides Report for 2014.

[3] Bertani, L. Labriola, C: Enrique Mosconi Project - 2014: "Aprovechamiento Energético del Bajo del Gualicho". Project suported by National State obtained by national contest.

[4] Bertani, L., 2014: "Phisical Geography", internal book for lectures, Humanity Faculty of National University of Comahue. Chapter: Tides and Waves.

[5] Masera R., Guarido J., 2003: "Bajo del Gualicho: una planicie patagónica bajo el nivel del mar". Helth and Social Development Ministry of Rio Negro Province. ISBN 98797315-2-2.

[6] Reichler V., 2010: "Estratigrafía y paleontología del Cenozoico marino del Gran bajo y Salinas del Gualicho, Argentina", and description of 17 new species. Andean Geology.http://dx.doi.org/10.4067/S0718-710620100001000 08. On-line version ISSN 0718-7106.

[7] Dracksler, S. 2013, Final Work of Renewable Energy lecture " Anteproyecto de Cenral mareomotriz en bajo del Gualicho", Faculty of Engineering, National University of Comahue, Neuquen, Argentina.

[8] COPIME, 2012: Presentation of Green Bones on Seminar of Renewable Energy and Environment organized by Professional Council of Mechanical and Electrical Engineers, Buenos Aires, Argentina.

[9] CAMMESA, 2013: Data from Annual Report 2013 by Whole Sale Market Administration Company, Rosario, Santa Fé, Argentina.

[10] GEN-REN, 2010: Mean value of $\mathrm{kw} / \mathrm{instaled}$ foor Renewable energy sources fron Nacional Parchase of Renewable Energy Projects, Buenso Aires, Argentina.

[11] MIN-EC, 2013: Reporto f Nacional Economy fron Economic Ministry of Argentina, Buenos Aires.

[12] Biancucci, M., Labriola, C., 2008: World Renewable Energy Congreso: "Wind-Tidal Combined Generation System for Patagonia. Argentina. By Maximiliano Biancucci \& Carlos V.M. Labriola, from University of Comahue. Organizad by University of Strathclyde, Glagow, Scotiland, United Kingdom. 